\title{
On the Alienation of Academic Labour and the Possibilities for Mass Intellectuality
}

\author{
Richard Hall
}

De Montfort University, Leicester, UK, rhall1@dmu.ac.uk, http://richard-hall.org

\begin{abstract}
As one response to the secular crisis of capitalism, higher education is being proletarianised. Its academics and students, increasingly encumbered by precarious employment, debt, and new levels of performance management, are shorn of autonomy beyond the sale of their labour-power. Incrementally, the labour of those academics and students is subsumed and re-engineered for value production, and is prey to the twin processes of financialisation and marketisation. At the core of understanding the impact of these processes and their relationships to the reproduction of higher education is the alienated labour of the academic. The article examines the role of alienated labour in academic work in its relationship to the proletarianisation of the University, and relates this to feelings of hopelessness, in order to ask what might be done differently. The argument centres on the role of mass intellectuality, or socially-useful knowledge and knowing, as a potential moment for overcoming alienated labour.
\end{abstract}

Keywords: Academic Labour, Alienation, Higher Education, Mass Intellectuality, Proletarianisation

\section{Introduction: Academic Labour in Crisis}

Academic labour is globally being restructured in response to the secular crisis of capitalism (Bellamy Foster and Yates 2014; Hall 2015). Such restructuring emerges through a desperate need to expand the generation of surplus-value, which has catalysed the subsumption of previously socialised goods like healthcare, welfare and education under the dictates of financialisation and marketisation (Davies 2014). In spite of this subsumption, capital has been unable to reinstate stable forms of accumulation (Jappe 2014). As a result, this inability questions both the subordination of policy to economic determinism and the legitimacy of neoliberal regimes of governance.

The subsumption of higher education (HE) under the structuring logic of value has highlighted the weakening of autonomy for the academic labourer beyond the temporary amelioration of her labour relations with those who direct the University. This applies across the terrain of HE in terms of teaching, learning, research and administration, for both academics and students. Moreover, it plays out through a policy narrative with two functions. First, it fetishises specific capabilities related to the generation of human capital, and in particular entrepreneurialism and employability. Second, it increases the proletarianisation of academic labour through organisational development and technological rationalisation (Dyer-Witheford 2015, 19-38). One result is the internalisation of performativity and an increasing number of published narratives of academic and student ill-health or of their quitting the academy, and in particular of a rise in anxiety (Ball 2015; Hall and Bowles 2016).

These narratives signal a rupture in the academic psyche, as the processes through which the academic labour of staff and students is subsumed and reengineered are increasingly defined by "the social tyranny of exchange-value" 
(Wendling 2009, 52). Such ruptures are an outcome of the alienation of the academic labourer from: first, her labour-power, which is made precarious as it is sold in the market; second, the products of her labour, which are financialised and marketised for their exchange-value rather than their social utility; third, herself as she becomes a self-exploiting entrepreneur; and fourth, her humanity as a species-being, reinforced through global competition (Marx and Engels 1998/1846).

In understanding and then addressing the ways in which academics are reproduced as competing human capitals, it is necessary to reconnect the academic project to its genesis in alienated labour. In order to understand how processes of financialisation and marketisation are affecting the academic ego, by reshaping scholarship and research as knowledge transfer, through spillover activity and impact, and in redefining teaching as excellence (Newfield 2016), it is necessary to reconnect the categorical labour of academics to the site of its alienation. As Clarke $(1991,52)$ notes:

In alienated labour a social relation between people appears in the form of the subordination of a person to a thing. This social relation is the relation of private property, in which the capitalist appropriates the means of production as his private property, so permitting him to subordinate the labourer to his own will.

A discussion of the relationship between alienated labour, competition and the production/circulation/consumption of academic products is central to how we might reimagine the purposes of academic work. For Clarke (1991), this discussion pivots around alienated labour as the key to understanding the ways in which capitalist society mediates our activity, with a focus on their overcoming.

In revealing alienated labour as a site of the proletarianisation of academic labour, it is possible to ask: against this structural, secular alienation, might academic labour be re-evaluated for its social use? Against these stresses, is it possible to reclaim the university as site of struggle for both academics and students? This paper situates such a re-evaluation or reclamation against the idea of "mass intellectuality," or the possibility that academics and students might imagine that their skills, practices and knowledges can be shared and put to another use, in common and in co-operation (Hall 2014). This focuses on recovering the subjectivity of the student or academic as part of a social struggle focused upon pre-figurative and co-operative alternatives (Marx 1866; 1875; Marx and Engels 1998/1846). By engaging with concrete examples of how academics and students are working to overturn the conditions of their alienated labour, this responds to Clarke's $(1991,255)$ call "to resume the project which Marx initiated of linking an emancipatory social theory to an emancipatory social practice." Such a project situates the exploitation of academic labour against the wider exploitation of paid and unpaid labour in the social factory. Not only must the academic labourer overcome her own competition with other academics to reduce her exploitation, but she must situate this cognitively and emotionally against the abolition of wage-labour more generally.

\section{The Proletarianisation of Higher Education}

Dyer-Witheford (2015) argues that capitalism can be represented as an unstable, self-expanding and dynamic force field, or vortex. For Dyer-Witheford, one of the 
drivers of the energy flows inside the vortex is the ongoing proletarianisation of global labour, driven in-part cybernetically through the integration of humans and digital technologies. This integration occurs in the interstices between consumption, production and financialisation. Such a cybernetic re-imagination of work situates the labourer as part of a global machine of value production, whilst decomposing the technical composition of that labour.

$\mathrm{HE}$ is also caught up in these cyclonic processes of production, consumption and financialisation. In England this has been amplified through the rapid increase in student fees, the implementation of metrics like the National Student Survey and Longitudinal Education Outcomes, and institutional audits like the Research Excellence Framework and the Teaching Excellence Framework. Sitting inside a policy framework that includes the HM Treasury Productivity Plan (2015), the Small Business, Enterprise and Employability Act (Department for Business, Innovation \& Skills (DBIS) 2015), and the HE and Research Act (Department for Education (DfE) 2017a), these tactics have focused competition for student numbers and research funding at both the institutional and subject-level. As a result, competition instantiated through metrics and league tables dominates academic labour time, such that academics have increasingly little control over the surplus time that the University demands from them.

Competition is the completest expression of the battle of all against all which rules in modern civil society. This battle, a battle for life, for existence, for everything, in case of need a battle of life and death, is fought not between the different classes of society only, but also between the individual members of these classes. Each is in the way of the other, and each seeks to crowd out all who are in his way, and to put himself in their place (Engels 2009/1845, 111).

A driver for the proletarianisation of $\mathrm{HE}$ is the re-engineering of academic work, so that the focus becomes less the concrete labour that produces teaching materials, a journal article, or a report for public engagement. Instead, the focus shifts to the exchange-value that can be extracted from those products through research funding, knowledge transfer, impact or the fees that accompany student retention. Moreover, given the competitive framing for global $\mathrm{HE}$, generating efficiencies in time through technological and organisational innovations enables academic labour to be stripped of its intellectual content. The critical mediation becomes abstract academic labour, measured by the time it takes to produce research outputs and impact, feedback on assessments, and so on. Such innovations are predicated upon the development of the productive power of academic labour and an attrition on its costs. As a result, there is a flow between the following:

- the need for universities to compete and to remain productive through technological and organisational innovation, and new services, such as the implementation of Research Management Systems and learning analytics. This is enabled through a range of corporate partnerships, including those with software retailers, publishers, management consultants and venture capitalists (Carnegie Associates 2013; McKinsey and Company 2017; Pearson 2017); 
- the ability of universities to drive down the labour-time for assessing/teaching/publishing compared to rival institutions, so that it can maintain competitive advantage. Across the United Kingdom, this has led to the implementation of new forms of academic staff workload planning and performance management (Ball 2015);

- rises in casual precarious employment, because by driving down labour costs university senior managers can buy a greater mass of labour power or progressively replace skilled labourers by those who are less skilled. Globally, this affects precariously-employed academics (CASA 2017), precariously-indentured students (CUPE3903 2017), and those professional services staff with poor labour rights (United Voices of the Whole World Union 2017);

- changes in the technical conditions of the process of academic production, which enable new accumulations of academic products to become additional means of production. For instance, the enforcement of lecture capture or of digital learning strategies enables new academic commodities to open-up new markets, especially in the global South (Harris et al. 2012). This was one of the key drivers behind the Massive Open Online Course initiatives (Rizvi et al. 2013), and the rise of the for-profit sector (McMillan Cottom 2017; Newfield 2016);

- the need to sustain and grow surpluses that can be invested in estates and infrastructure projects. In part, this happens as academics set in motion more means of production, for instance by increasing student recruitment, undertaking innovative teaching and research in new markets, and investing more labour in producing digital learning environments (Winn 2015); and

- the drive to centralise and monopolise the production, circulation and accumulation of academic value through comparative national and international league tables, as well as via policy that enables new providers to enter existing HE markets alongside market exit for existing providers (DfE 2017a).

Through these interrelated processes a surplus, precarious population of academics emerges, in the form of postgraduates who teach, adjuncts, casual teachers, associate/full professors, and crucially students, who lack control over the means of production. Following Marx and Engels (2002/1848), we might argue that in order to overcome their surplus, precarious identities, these academic labourers have two options. First, to sell themselves piecemeal, in their teaching, assessment, feedback, research, scholarship, knowledge exchange and impact. Second, to take on increased levels of debt in the hope of generating innovative human capital.

Thus, globally there are: first, reports of adjunct professors who "don't even earn the federal minimum wage" (Saccaro 2014); second, struggles led by postgraduate researcher-led committees that push the University to honour the essential role of teaching assistants in the form of fair pay and labour rights (CUPE3903 2017); third, quitlit reports of academics leaving the profession (Morris 2015); fourth, individuals who witness self-imposed overwork as a form of self-harm; fifth, reports of the suicides of those who are classified as precarious, or for whom status is being removed; and sixth, networks reporting on casualisation (CASA 2017). These realities of proletarianisation form filaments that enable us to trace its roots in alienated labour.

\section{Alienated Labour}

In working towards an alternative to proletarianisation, a critical, negative starting point is to uncover the alienated genesis of academic labour. This, then enables a focus on its overcoming or abolition, as an emancipatory social practice that prefig- 
ures a reimagining of the relationship between higher education and society. In reaching below the surface effects of the reengineering of $\mathrm{HE}$ through competition and value production, we need to address how this appears both as a process of dispossession of time, agency and autonomy for academics and students, and as the appropriation of concrete labour from the standpoint of capital (Marx 1993/1857, 831). A pivot for this analysis is a focus on subjectivity.

Marx's critique of liberalism sought to recover, both in theory and in practice, the constitutive role of human subjectivity behind the immediacy of objective and constraining social relations within which our social identity confronts us in the form of an external thing (Clarke 1991, viii-ix).

Here, the social relationships that define capitalist reality are constructed through historically-specific relations of production, which are themselves rooted in the dispossession and appropriation of everyday, practical and sensuous activity (Marx 2014/1844; Marx and Engels 1998/1846). As Clarke (1991) argues, at the root of Marx's critique of capital was the analysis of how such activity was alienated under capitalism. Here, the apparent starting point is commodity production: "The wealth of societies in which the capitalist mode of production prevails appears as an "immense collection of commodities"; the individual commodity appears as its elementary form" (Marx 2004/1867, 125). In a system of commodity production:

The worker becomes poorer the more wealth he produces and the more his production increases in power and extent. The worker becomes an ever cheaper commodity the more goods he creates. The devaluation of the human world increases in direct relation with the increase in value of the world of things. Labor does not only create goods; it also produces itself and the work as a commodity, and indeed in the same proportion as it produces goods. (Marx 2014/1844, 82)

Moreover, flowing from the sale of labour-power as a commodity, and underpinning alienated labour, is the objectification of labour as it is embodied in the production of physical things, which then come to dominate life:

[...] the object produced by labor, its products, now stands opposed to it as an alien being, as a power independent of the producer. The product of labor is labor which has been embodied in an object and turned into a physical thing; this product is an objectification of labor. The performance of work is at the same time its objectification, the performance of work appears in the sphere of political economy as a vitiation of the worker, objectification is a loss and a servitude to the object, and appropriation is alienation (Marx 2014/1844, 83). 
The labourer's activity is alienated from her precisely because it cannot satisfy her intrinsic needs. At best, it provides means of subsistence. At worst it requires increasing amounts of cognitive dissonance in order both to re-enter the market to resell her labour-power, and to believe that she loves/likes what she does. This takes the form of further self-alienation. Whilst the arguments for entrepreneurialism, employability and the development of human capital inside HE are situated superficially in the development of the individual and her capabilities, as wants that emerge from inside her, they are a function of the desire to expand value production. This is witnessed in the ongoing disciplining of that academic labour-power through performance management and metric-based monitoring (Ball 2015; Pearson 2017). In the process, alienated labour forms the basis of competition, and through it the separation of the individual from her wider communities (Marx, 2014/1844).

From the starting point of alienated labour, private property and thus the domination of capital over the worker emerges. The social necessity of the sale of labourpower for the reproduction both of the labourer and her society, creates an asymmetrical relation of labour to the capital. Thus, the mediation of private property emerges from alienated labour (Marx 2014/1844). For Clarke (1991, 54), it is important to base an analysis of alienation on the relations of production inside capitalism, and to "penetrate beneath the alienated form of labour to see the fundamental contradiction between labour, as the active agent of production, and its alienated (commodity) form which explains both its foundation and the possibility of its overcoming."

Here one of the most important outcomes for academic labour is that a critique of its political economy demonstrates how the focus on status underpins liberal society's preoccupation with private property (including intellectual property and intellectual/social capital). Through such a critique, the foundation of private property (in this case the ownership of academic labour-power) is shown to be social and historical, rather than natural and trans-historical. This opens-up possibilities for challenging the neoliberal obsession with competition, performance management, data-driven risk management, and the generation of abstract human capital. Instead it enables us to challenge the historical, relations of production that characterise academic work, and to generate alternatives. As Clarke argues $(1991,55)$, "If alienated labour is the basis of property, the abolition of property can only take the form of the abolition of alienated labour."

Thus the emancipation of society from private property, etc., from servitude, is expressed in the political form of the emancipation of the workers; not that their emancipation alone is at stake, but because the emancipation of the workers contains universal human emancipation (Marx 2014/1844, 91).

Across the social terrain, the process of overcoming does not depend upon responses to the mediations of performance management. Rather, it depends upon revealing the relationships between alienated labour, the ownership of labour-power and its products, and structures of commodity exchange that are predicated upon the division of labour and private property (Mészáros 2005).

These processes of alienation are amplified because commodity exchange, and in particular the exchange of labour-power, is mediated by money. As Marx noted $(2014 / 1844,175)$, "The need for money [...] the true need produced by the modern economic system, and it is the only need which the latter produces." In part, this ex- 
plains the increasing focus across $\mathrm{HE}$ on data and metrics, as a way through which financialisation can be mediated (DfE 2017b; McGettigan 2015). The ability to test research, teaching quality, learning environment, and student outcomes across individual institutions, and then to compare them across national and international educational terrains, becomes a way in which the functions of universities can become locked into the capitalist vortex.

Increasingly money replaces the real object and dominates the subject. In it needs and powers coincide in an abstract way: only those needs are recognized as real needs by an alienated society which can be bought by money i.e. which are within the reach and power of money (Mészáros 2005, 179).

What is hidden or revealed, depending on the level of analysis of financialisation, is the idea/purpose and content of the university as it is structured through academic labour. However, one result is to uncover how the mediations of private property commodity exchange - division of labour infect the university just as they do any other firm, and education as they do any sector of the economy. However, it is only possible to understand the role of financialisation and marketisation, as highly developed forms of private property, through an analysis of the commodification of education, with alienated labour as its point of origin. As Marx argued (2014/1844, 129), "The division of labour is the economic expression of the social character of labour within alienation [...] The division of labour is nothing but the alienated establishment of human activity as real species-activity or the activity of man as a species-being." For Clarke $(1991,59)$, the starting point for a re-imagination of the society is uncovering "the alienated power of social labour."

Such social powers accelerate the processes of proletarianisation noted above, and which are made visible through metrics and performance data, outsourcing and precarious employment, a focus on knowledge transfer and impact, and so on. What is revealed is academic alienation: "Hence the rule of the capitalist over the worker is the rule of things over man, of dead labour over living, of the product over the producer" (Marx 2004/1867, 990). In overcoming such alienation, academics enter into internal and external conflicts. On the one hand, they see their work as contributing to student satisfaction or perceptions of student freedom or autonomy as economic actors possessing new forms of human capital. Here, they also see their own work in terms of its wider societal use, and this is predicated upon abstract ideals of academic freedom and institutional autonomy. On the other hand, such work is increasingly disciplined for exchange-value, and the surplus time given to the production of academic commodities amplifies overwork. The cognitive dissonance between, first, the perceptions of academics that their work has use-value, and, second, the reality that it is subsumed under exchange-value, is increasingly revealed as world-weariness or weltschmerz.

\section{Weltschmerz}

For some academics, weltschmerz, or a world weariness that lies beyond anxiety, anguish or ennui, reflects a deeper sense of hopelessness about the academic project. This is a recognition that the world once hoped for may never be, and that the concrete world now abstracted for value may never embody our deeper humanity. In 
fact, in our abstracted world such hopelessness is connected to a loss of autono$\mathrm{my} / \mathrm{freedom}$ that is itself rooted in the inability to escape from capital's domination. Much worse is the fact that the cultural terrain upon which capital works reinforces within us a sense that we are not productive enough, and that this is a sin (Jappe 2014).

As one response, new ideas of good/public and bad/private are projected onto the University (Campaign for the Public University (CPU) n.d., Council for the Defence of British Universities (CDBU) n.d.). However, as the politics of austerity restricts academic autonomy, alternative responses include either incorporating performativity or internalising the loss of what the university might become. Either position risks the development of a new depressive position through which the overwhelming feeling is one of hopelessness. Overcoming such a depressive position requires a different level of grief and mourning to be internalised, so that academics can address their alienation in an authentic manner, and in relation to wider society.

Hopelessness is rooted in the academic's apparent loss of her labour, as it is brought into the service of value. Marx (1844) argued that this is the logic of capitalism as it defenestrates labour, in order that it can accumulate autonomy:

Is then only the semblance of an activity, only a forced activity, imposed upon me only by an external and accidental necessity and not by an internal and determined necessity [...] My labour, therefore, is manifested as the objective, sensuous, perceptible, and indubitable expression of my self-loss and my powerlessness.

Such powerlessness is a reflection of how social or communal spaces, places, identities, and relationships become means of extracting value or hoarding private wealth. Moreover, with the formal subsumption of HE under capitalist social relations, a sense of hopelessness is reinforced as we witness just how far the limits to our alienation from space, society and nature can be pushed. As Berardi $(2009,73)$ argues:

To be recognized in the networked universe one must become compatible with the generative logic of the matrix. What does not belong to a codified domain is not socially recognizable or relevant, although it still exists in the domain of irrelevance, of residuality. It then reacts with rage and despair, in order to violently reassert its existence.

At issue is how agency, or the reassertion of academic autonomy, might be enacted in the face of a technological system that co-opts and reproduces social relationships for the production of value. As academics are torn between ideas of social/public good and individual entrepreneurial activity, cultures of omertà emerge. This is the silence of those in the know, who must co-operate even as they compete, and thereby generate complex inter-relationships rooted in uncertainty and anxiety (Hall and Bowles 2016). In moving beyond this negative critique, the question is how to negate rather than accommodate the basis of domination? Is it possible to imagine a new form of sociability? For Marx $(2014 / 1844,82)$, this reveals the contradictions at the heart of a marketised, economised existence that is predicated on the "increasing 
value of the world of things" at the expense of the "devaluation of the world of men." The question is whether that world can be superseded across the social factory (Federici, 2012), and the role of the university in that overcoming? Here the concept of "mass intellectuality" is a useful heuristic.

\section{The Possibilities for Mass Intellectuality}

The idea of "mass intellectuality" erupts from within the Autonomist Marxist tradition, tracing its lineage to Marx's notion of the "general intellect" (Dyer-Witheford 1999; Virno 1996). Marx $(1993 / 1857,694)$ argued that the dynamics of capitalism meant "the accumulation of knowledge and of skill, of the general productive forces of the social brain, is thus absorbed into capital, as opposed to labour, and hence appears as an attribute of capital, and more specifically of fixed capital [machinery]." The drive to subsume labour formally under the structuring dynamics of value production, underpins organisational development and technological innovation, which themselves emerged through competition over the accumulation of relative surplus value. As a result, the craft and technical skills, capabilities, and knowledge of the social individual are continually absorbed into the things she produces. Therefore, the "general intellect" of society, i.e. its general capacity for natural science fused with philosophy in the broadest sense, is absorbed into capitalised technologies and techniques. Whilst the focus for this is to reduce labour costs and to increase productivity, it corrupts the ability to think critically about the human experience and to solve problems at the level of society (Marx 2014/1844). Instead the focus is on marketised or outsourced solutions to crises.

Starting from an Autonomist position it is important to understand the mechanisms through which the general intellect is co-opted for value production (Virno 2004), so that it might be reclaimed. Thus, the relationship between general intellect and mass intellectuality points beyond the fetishised myth of technology and entrepreneurial activity as the origins of value. Whilst mass intellectuality refers to knowledge and forms of knowing that capital seeks to valorise, it also points towards the immanent (negative) and pre-figurative (positive) potential of new forms of sociability. Mass intellectuality implies a struggle over the proletarianisation of labour, and its emancipatory implications, as the embodiment of the cumulative history of natural science and philosophy. From the standpoint of mass intellectuality, an analysis of the ways in which 'immaterial' production or affective labour and cognitive capital emerge from within structures that are predicated upon alienated labour, enables a critique of the relations of production and a critical understanding of the constant drive to innovate using technology (Manzerolle 2010).

A critique that is based upon alienated labour points towards a focus on alternative educational practices that develop socialised knowledge, or 'mass intellectuality', as a direct, social force of production. This is an attempt to reclaim the concept of living knowledge as useful work, and to reimagine sociability or to define activities that reproduce society against-and-beyond value production. It forms a critique of subjectivity in its relationship to the prevalent mode of (knowledge) production. The potential is for the liberation: first, of those craft and technical skills, capabilities, and knowledge of the social individual that have been absorbed into the things the academic produces; and second, of the academic from the process of production and ultimately from her academic labour and the sale of her academic labour-power. As a form of sociability that it is not restricted by capitalist time, these activities might structure and determine that time for other, autonomous ends (Postone 1996). 
As the University of Utopia (n.d.) argued, a reconsideration of the relationship between general intellect and mass intellectuality, in order to recover the former in the form of the latter, points towards the abolition of alienated labour.

In the society of abundance the university as an institutional form is dissolved, and becomes a social form or knowledge at the level of society (i.e. The General Intellect). It is only on this basis that we can knowingly address the global emergencies with which we are all confronted (University of Utopia n.d.).

In this process new forms of subjectivity emerge that the point beyond labour, and therefore refuse the creation of status divisions inside a reinvigorated capitalist hierarchy. This work is predicated upon co-operation (Marx 1866, 1875; Neary and Winn 2017).

\begin{abstract}
Mass intellectuality is based on our common ability to do, based on our needs and capacities and what needs to be done. What needs to be done raises doing from the level of the individual to the level of society (University of Utopia n.d.).
\end{abstract}

Thus, struggles both inside and outside of the university, to build counter-hegemonic positions rooted in solidarity and sharing, and related to the social and co-operative use of the knowledge, skills and practices that are created by labour, might be analysed in terms of mass intellectuality (Hall and Winn 2017).

One such example is the Social Science Centre (2017) in Lincoln, UK, which can be characterised as a laboratory for co-operative production, consumption and distribution of higher learning. The space is rooted in democratic organising principles (governance) for both the Centre and its activities, and its content (for instance, childcare arrangements, curricula, events). The Centre's pedagogical underpinnings are grounded in democracy, co-operation and solidarity, enriched through a critique of critical pedagogy (Neary $2011 ; 2017$ ). Such a radical re-conceptualisation of the relationship between higher learning and society has also informed the Dismantling the Master's House project (DTMH 2015), which emerged at University College London. This work has emerged deliberately as a collective, student and staff process of questioning the colonial legacies reproduced in the governance, design, delivery and assessment of the curriculum. It questions whether a canonical curriculum, rooted in a specific, abstracted cultural view of the world, can be anything other than 'monstrous'? Indeed, can it enable societies to confront global emergencies that have emerged from the dominance of that very cultural view of the world? The end point for the project is to enact forms of educational repair that are themselves forms of societal repair, because they use the curriculum as a point of departure for delegitimising specific forms of alienation rooted in ongoing historical and material racism (Rhodes Must Fall Oxford 2017).

This work aligns with Neary's (2011, n. pag.) focus on 'the possibility and necessity of progressive social transformation through practical action', with the curriculum forming a space for praxis, rooted in the legitimisation of a counter-narrative. Such counter-narratives have a historical and material basis, which demonstrate the ability 
to organise higher learning inside-and-beyond the Academy with the purpose of solving concrete problems or mitigating/adapting to moments of crisis. For some, this involves forms of resistance and occupation inside the University (After the Fall 2009; Harney and Moten 2013). Elsewhere such reorganisation occurs within formal cooperatives (Mondragon University 2017; Neary and Winn 2017), or in the educational work of social movements (Friends of the Movimento dos Trabalhadores Rurais Sem Terra (MST) 2017; Occupy London 2012; Zibechi 2013). In these more radical spaces, mass intellectuality as a form of reclamation and renewal involves exploring the relationship between affirmative self-actualisation (hooks 1994) and the negative critique of established positions. In the process of reclamation and renewal, a politics of educational autonomy (Dinerstein, 2015) emerges as a form of collective, potential pedagogic energy. For hooks (1994), this is a capacity to live more fully and deeply, and to share in the intellectual and spiritual growth of students and teachers.

These alternative conceptualisations point towards co-operative HE as offering the possibility to critique the purposes for which the general intellect is commodified rather than made socially-useful. Crucially, relating academic labour to its moment of alienation might act as one critical site in the social struggle to recuperate the general intellect. However, this demands that the products and processes of labour generated at the edges of capitalist work, for instance in education commons, co-operative centres or social movements, are explicitly related to the struggle against alienated labour. The value of mass intellectuality lies in its potential to reveal, critique and overcome alienated labour.

In terms of academia, such an abolition cannot occur in isolation and needs to be connected to the multitudinous refusals of labour inside-and-against the capitalist vortex. Here there must be a refocusing of the academic as a socialised worker, in her relationship to the social factory and to social reproduction. As a result, situating the reproduction of the University and of academic labour against intersectional resistances, in particular the gendered and racialised nature of the relationship between HE and society, forms a moment in the development of co-operative counternarratives (Marx 1866).

In this framing, mass intellectuality offers the potential for the democratic or cooperative reproduction of higher learning at the level of society and rooted in multiple ways of knowing the world. This rejects the mediations of private property, commodity exchange and the division of labour, which are themselves rooted in alienated labour and which define the capitalist university. In considering the possibility for dissolving their labour into the fabric of society, academics might prefigure new forms of productive, scientific and social knowledges, and ways of knowing.

Central to Marx's conception of the overcoming of capitalism is his notion of people's reappropriation of the socially general knowledge and capacities that had been constituted historically as capital. We have seen that, according to Marx, such knowledge and capacities, as capital, dominate people; such re-appropriation, then, entails overcoming the mode of domination characteristic of capitalist society, which ultimately is grounded in labor's historically specific role as a socially mediating activity. Thus, at the core of his vision of a postcapitalist society is the historically generated possibility that people might begin to con- 
trol what they create rather than being controlled by it (Postone 1996, 373).

\section{What Is to Be Done?}

Scott (1987) argues for generating currents of resistance that: are collective and organised; are principled and selfless; have revolutionary consequences; and negate rather than accept the basis of domination. However, the generation of such resistances, across an intersectional set of terrains that acknowledge issues of privilege and apparent powerlessness, require us to recognise how the triptych of private property, commodity exchange and division of labour mask the realities of alienated labour. Given emerging stories of distress across the terrain of $\mathrm{HE}$, which mirror those that emerge in other seams of the social factory, the pandemic of ill-health and overwork cannot be overcome by liberating labour. Instead, resistances that are collective, selfless, revolutionary, and imminent, must be developed pre-figuratively against labour (Amsler 2015; Motta and Cole 2014).

For academics, one way in which such prefigurative activity might be developed is by resisting the compartmentalisation and fragmentation of ourselves so that we are simply seen as academics, teachers, researchers or students, who are impactful. As Marx (2004/1867, 799) notes, this tends to 'mutilate the labourer into a fragment of a man'. Here, mass intellectuality offers a means to re-conceptualise and re-purpose our shared abilities, needs and capacities. One strategy has been to find 'space for casual, adjunct and sessional staff and their allies in Australian higher education to share resources and experiences, and to learn from each other' to support 'long-term casuals in universities whose experience is not reflected in the way that universities plan' (CASA 2017). A second strategy has been to consider where it is possible to say 'no' collectively inside the University, through solidarity actions between students, precariously-employed or untenured academics, professors, and professional services staff. For instance, the 3 cosas campaign (2015) for sick pay, holiday, and pension rights for contract staff at the University of London has now been connected to the International Workers Union of Great Britain. A third strategy has been to focus on immediate, strategic actions like resistance to the Research and Innovation Performance Expectations at Newcastle University (University and College Union at Newcastle 2016). This successfully refused the drive to commodify academic labour time through performance management, workload planning and on-going technological innovation, as means of exploitation. However, these strategies also highlight the importance of working deliberatively against intersectional oppressions, and to carry that deliberative work beyond the University into the fabric of society.

Here the terrain of personal narratives grounded in alienation, which have yet to reveal their root in alienated labour, open-up the possibility that we might discuss an overcoming of academic competition and overwork. O'Dwyer notes how such an abolition or overcoming requires that we start from narratives that highlight how uncertainty generates forms of academic post-traumatic stress.

Twelve years of uncertainty and instability has taken its toll. Multiple moves have taught me never to get too comfortable; to not recycle the packing boxes but instead keep them at the back of the closet. As a result of the unpredictable mix of fellowship successes and rejections, I have internalised the message that I am not good enough. Too many 'down to the wire' moments - in which 
I was forced to wait until just a few weeks before a contract ended to find out if I would have another - have made me question my worth. And so I keep waiting for the other shoe to drop. I keep wondering why they hired me. (O’Dwyer 2016)

However, developing a counter-hegemonic solidarity requires that such narratives are connected to both a critique of academic labour, and the development of social solidarity and the social strike. This situates the exploitation of academic labour against the wider exploitation of paid and unpaid labour in the social factory (Federici 2012). Of course, this must be attempted in association, so that an alternative intellectual, physical and humane existence might offer new forms of sociability that are grounded in autonomy.

A crucial element of this is control over time, and the struggle to make time for practical, material activities, rather than ruthlessly reducing the time available for those activities based on value-for-money and efficiency.

[I]n the communist future, which is not subject to the calculus of value, time must diminish in importance. When we extrapolate Marx's visions of free time, therefore, we must not only envision the lengthening of the disposable hours the worker marks between short stints of productive labor. We must instead imagine a modern life freed from time, or at least modern life freed from time's abstract and alienating dominations (Wendling 2009, 199).

Following Marx (2014/1844), this presupposes that the knowledges, skills and capacities of the academic can be reintegrated across society, rather than controlled by clock-time inside HE. Such repurposed social and communal activity, emerging from a new appreciation of knowledge and knowing, enables a different, concrete set of associations as direct expressions of sociability. This requires praxis in the form of mass intellectuality at the level of society, rather than being corralled as mass education within specific institutions like universities or inside specific, commodified curricula. This is best represented by community-based experiments outside the university (Lazarus 2017; Social Science Centre 2017), or inside social movements (MST 2017; Thorburn 2012). As Marx $(2014 / 1844,115)$ argues, 'The resolution of the theoretical contradictions possible only through practical means, only through the practical energy of man.'

In working to overcome alienated labour, praxis demands sitting with and then teaching hopelessness, in order to develop an authentic negative critique. It is then fundamental to use such a critique prefiguratively to think through the potential for waves of struggle, which demonstrate solidarity between various groups of workers and others across society impacted by austerity. Points of solidarity between HE and the social factory include: the embodied toll that neoliberal restructuring and austerity takes on mental and physical health, including across families; the control of lifeactivity through debt, precarious employment and performance management; the reduction of life to entrepreneurship and employability; the assault on social justice, and labour and human rights; and, the inability of the curriculum to manage issues of crisis concerning poverty, climate change, on-going colonialism and so on. 
Here there is a need to redefine the terms of resistance as cross-sectoral, acting communally or socially, precisely because those communal or social aspects of our identities are being marginalised or reduced, as work and productivity becomes totalising. There is a need to see this work as educational, rooted in a governance framework and organisation that prefigures what we desire. Such forms of resistance question the very nature of our academic labour, and ask how the work of students and academics can dismantle that labour as the starting point of alienation, in order to liberate what is socially-useful (DTMH 2015). This is an active becoming, and demands that academics refuse to be indifferent to their alienated labour, and their selfalienation. Here, our weltschmerz offers a starting-point for uncovering the relationship between proletarianisation and alienation, which in turn offers hope for reimagining higher learning through mass intellectuality. This is our socially-useful, pedagogic task.

\section{References}

After The Fall. 2010. Communiqués from Occupied California. Accessed July 29, 2017. http://libcom.org/files/afterthefall communiques.pdf

Amsler, Sarah. 2015. The Education of Radical Democracy. London: Routledge.

Ball, Stephen. 2015. Accounting for a Sociological Life: Influences and Experiences on the Road from Welfarism to Neoliberalism. British Journal of Sociology of Education 36 (6): 817-831.

Bellamy Foster, John and Michael Yates. 2014. Piketty and the Crisis of Neoclassical Economics. Monthly Review. Accessed July 29, 2017.

http://monthlyreview.org/2014/11/01/piketty-and-the-crisis-of-neoclassical-economics

Berardi, Franco. 2009. The Soul at Work: From Alienation to Autonomy. Los Angeles: Semiotext(e).

Carnegie Associates. 2014. MOOCs: Opportunities for Their Use in Compulsory-Age Education. DfE Research Report. Accessed July 29, 2017. https://www.gov.uk/government/uploads/system/uploads/attachment data/file/315591/DfE RR355 - Opportunities for MOOCs in schools FINAL.pdf

Clarke, Simon. 1991. Marx, Marginalism and Modern Sociology: From Adam Smith to Max Weber. London: Palgrave.

CASA. 2017. A Home Online for Casual, Adjunct, Sessional Staff and Their Allies in Australian Higher Education. Accessed July 29, 2017. http://actualcasuals.wordpress.com

CDBU. 2017. Council for the Defence of British Universities. Accessed July 29, 2017. http://cdbu.org.uk

CPU. 2017. Campaign for the Public University. Accessed July 29, 2017. http://publicuniversity.org.uk

CUPE3903. 2017. Representing, Organizing and Activating the Contract Faculty, Teaching Assistants, Graduate Assistants, and Research Assistants @ York University, Toronto, Canada. Accessed July 29, 2017. http://3903.cupe.ca

Davies, Will. 2014. The Limits of Neoliberalism: Authority, Sovereignty and the Logic of Competition. London: SAGE.

DBIS. 2015. The Small Business, Enterprise and Employment Act. London: HM Stationery Office. Accessed July 29, 2017. http://www.legislation.gov.uk/ukpga/2015/26/pdfs/ukpga 20150026 en.pdf

DfE. 2017a. The Higher Education and Research Act. London: HM Stationery Office. Accessed July 29, 2017. http://www.legislation.gov.uk/ukpga/2017/29/pdfs/ukpga 20170029 en.pdf

DfE. 2017b. Graduate Outcomes for All Subjects by University. London: DfE. Accessed July 29, 2017. https://www.gov.uk/government/statistics/graduate-outcomes-for-all-subjectsby-university 
Dinerstein, Ana. 2015. The Politics of Autonomy in Latin America: The Art of Organising Hope. London: Palgrave Macmillan.

DTMH. 2015. Dismantling the Master's House. Accessed July 29, 2017. http://www.dtmh.ucl.ac.uk

Dyer-Witheford, Nick. 2015. Cyber-Proletariat: Global Labour in the Digital Vortex. London: Pluto Press.

Dyer-Witheford, Nick. 1999. Cyber-Marx: Cycles and Circuits of Struggle in High Technology Capitalism. Urbana: University of Illinois Press.

Engels, Friedrich. 2009/1845. The Condition of the Working Class in England. London: Penguin.

Federici, Sylvia. 2012. Revolution at Point Zero: Housework, Reproduction and Feminist Struggle. Oakland: PM Press.

Hall, Richard. 2015. The University and the Secular Crisis. Open Library of Humanities. Accessed July 29, 2017. http://doi.org/10.16995/olh.15

Hall, Richard. 2014. On the Abolition of Academic Labour: The Relationship Between Intellectual Workers and Mass Intellectuality. tripleC: Communication, Capitalism \& Critique 12 (2): 822-837. Accessed July 29, 2017. http://triple-c.at/index.php/tripleC/article/view/597

Hall, Richard and Kate Bowles. 2016. Re-engineering Higher Education: The Subsumption of Academic Labour and the Exploitation of Anxiety. Workplace: A Journal for Academic Labor 28: 30-47. Accessed July 29, 2017. http://bit.ly/2dQMx8X

Hall, Richard and Joss Winn, eds. 2017. Mass Intellectuality and Democratic Leadership in Higher Education. London: Bloomsbury Academic.

Harney, Stefano and Fred Moten. 2013. The Undercommons: Fugitive Planning \& Black Study. Brooklyn: Minor Compositions.

Harris, Karen, Andrew Schwedel and Austin Kim. 2012. A World Awash in Money. Accessed July 29, 2017. http://www.bain.com/publications/articles/a-world-awash-in-money.aspx

HM Treasury. 2015. Fixing the Foundations: Creating a More Prosperous Nation. London: HM Treasury. Accessed July 29, 2017.

https://www.gov.uk/government/uploads/system/uploads/attachment data/file/443898/Pro ductivity Plan web.pdf

hooks, bell. 1994. Teaching to Transgress: Education as the Practice of Freedom. London: Routledge.

Jappe, Anselm. 2014. Towards a History of the Critique of Value. Capitalism, Nature, Socialism 25 (2): 25-37.

Lazarus, Joel. 2017. Reconciling mass Intellectuality and higher Education: Lessons from the PPE Experience. In Mass Intellectuality and Democratic Leadership in Higher Education, edited by Richard Hall and Joss Winn, 141-55. London: Bloomsbury Academic.

Manzerolle, Vincent. 2010. The Virtual Debt Factory: Towards an Analysis of Debt and Abstraction in the American Credit Crisis. tripleC 10 (2): 221-36. Accessed July 29, 2017. http://www.triple-c.at/index.php/tripleC/article/view/149

Marx, Karl. 2014/1844. Economic and Philosophical Manuscripts. London: Bloomsbury.

Marx, Karl. 2004/1867. Capital, Volume 1: A Critique of Political Economy. London: Penguin.

Marx, Karl. 1993/1857. Grundrisse: Outline of the Critique of Political Economy. London: Penguin.

Marx, Karl. 1875. Critique of the Gotha Program. Accessed July 29, 2017. https://www.marxists.org/archive/marx/works/1875/gotha

Marx, Karl. 1866. Instructions for the Delegates of the Provisional General Council: The Different Questions. Accessed July 29, 2017. http://www.marxists.org/archive/marx/works/1866/08/instructions.htm

Marx, Karl. 1844. Comments on James Mill. Accessed July 29, 2017. http://www.marxists.org/archive/marx/works/1844/james-mill

Marx, Karl and Friedrich Engels. 2002/1848. The Communist Manifesto. London: Penguin. 
Marx, Karl and Friedrich Engels. 1998/1846. The German Ideology: Including Theses on Feuerbach and Introduction to the Critique of Political Economy. New York: Prometheus.

McGettigan, Andrew. 2015. The Treasury View of HE: Variable Human Capital Investment. Political Economy Research Centre Papers Series 6. Accessed July 29, 2017. http://www.perc.org.uk/perc/wp-content/uploads/2015/04/PERC-6-McGettigan-and-HEand-Human-Capital-FINAL-1.pdf

McKinsey and Company. 2017. Education. Accessed July 29, 2017. http://mckinsey.com/industries/social-sector/how-we-help-clients/education

McMillan Cottom, Tressie. 2016. Lower Ed: The Troubling Rise of For-Profit Colleges in the New Economy. New York: The New Press.

Mészáros, István. 2005. Marx's Theory of Alienation. London: Merlin Press.

Mondragon University. 2017. What is Mondragon University? Accessed July 29, 2017. http://www.mondragon.edu/en/about-us/what-is-mu

Morris, Amanda. 2015. The Rise of 'Quit Lit': What It Is and Why It Matters [Opinion]. Noodle.com. Accessed July 29, 2017. http://bit.ly/2dAimp9

Motta, Sara and Mike Cole. 2014. Constructing $21^{\text {st }}$ Century Socialism in Latin America: The Role of Radical Education. New York: Palgrave Macmillan.

MST. 2017. What is the MST? Accessed July 29, 2017. http://www.mstbrazil.org/content/what-mst

Neary, Mike. 2017. Pedagogy of Hate. Policy Futures in Education. Accessed July 29, 2017. https://doi.org/10.1177/1478210317705742

Neary, Mike. 2011. Student as Producer: A Pedagogy for the Avant-Garde; Or, How Do Revolutionary Teachers Teach? Learning Exchange 1 (1). Accessed July 29, 2017. http://eprints.lincoln.ac.uk/4186/

Neary, Mike and Joss Winn. 2017. There is an Alternative: A Report on an Action Research Project to Develop a Framework for Co-operative Higher Education. Learning and Teaching: The International Journal of Higher Education in the Social Sciences 10 (1): 87-101.

Newfield, Christopher. 2016. The Great Mistake: How We Wrecked Public Universities and How We Can Fix Them. Baltimore: Johns Hopkins University Press.

Occupy London. 2012. Tent City University. Accessed July 29, 2017. http://occupylondon.org.uk/category/working-groups/tent-city-university

O'Dwyer, Siobhan. 2016. This (Un)certain Life. Accessed July 29, 2017. https://researchthatcares/2016/03/13/this-uncertain-life

Pearson. 2017. Efficacy and Research. Accessed July 29, 2017. http://www.pearson.com/corporate/efficacy-and-research.html

Postone, Moishe. 1996. Time, Labor and Social Domination: A Reinterpretation of Marx's Critical Theory. Cambridge: Cambridge University Press.

Rhodes Must Fall Oxford. 2017. Accessed July 29, 2017. https://rmfoxford.wordpress.com

Rizvi, Saad, Katelyn Donnelly and Michael Barber. 2013. An Avalanche is Coming: Higher Education and the Revolution Ahead. Institute for Public Policy Research. Accessed July 29, 2017. http://www.ippr.org/publications/an-avalanche-is-coming-higher-education-andthe-revolution-ahead

Saccaro, Matt. 2014. Professors on Food Stamps: The Shocking True Story of Academic in 2014. Salon. Accessed July 29, 2017.

http://www.salon.com/2014/09/21/professors on food stamps the shocking true story of academia in 2014/

Scott, James. 1987. Weapons of the Weak: Everyday Forms of Peasant Resistance. Yale: Yale University Press.

The Social Science Centre. 2017. Accessed July 29, 2017. http://socialsciencecentre.org.uk

Thorburn, Elise. 2012. Actually Existing Autonomy and the Brave New World of Higher Education. Occupied Studies. Accessed July 29, 2017. http://bit.ly/xzcPRO

Universities and Colleges Union at Newcastle. 2016. A Local Victory of National Significance: Branch Secretary's Report, 2015-2016. Accessed July 29, 2017. 
http://newcastle.web.ucu.org.uk/a-local-victory-of-national-significance-branch-secretarysreport-2015-6

The University of Utopia. 2014. Anti-Curricula: A Course of Action. Accessed July 29, 2017. http://www.universityofutopia.org/sharing

United Voices of the Whole World Union. 2017. Justice for LSE Cleaners. Accessed July 29, 2017. https://www.uvwunion.org.uk/uvwnews?category=Justice+for+LSE+Cleaners

Virno, Paolo. 2004. A Grammar of the Multitude. Los Angeles: Semiotext(e).

Virno, Paolo. 1996. Virtuosity and Revolution. In Radical Thought in Italy: A Potential Politics, edited by Michael Hardt and Paolo Virno, 190-201. Minneapolis: University of Minnesota Press.

Wendling, Amy. 2009. Karl Marx on Technology and Alienation. London: Palgrave Macmillan.

Winn, Joss. 2015. Writing About Academic Labour. Workplace: A Journal for Academic Labor 25: 1-15. Accessed July 29, 2017. http://ices.library.ubc.ca/index.php/workplace/article/view/185095.

Zibechi, Raúl. 2013. Autonomous Zapatista Education: The Little Schools of Below. Accessed July 29, 2017. http://upsidedownworld.org/archives/mexico/autonomous-zapatistaeducation-the-little-schools-of-below

3 cosas campaign. 2014. Accessed July 29, 2017. http://3cosascampaign.wordpress.com

\section{About the Author}

Richard Hall

Richard Hall is Professor of Education and Technology at De Montfort University, Leicester, UK. At DMU he is Co-Director of the Institute for Education Futures (http://ief.our.dmu.ac.uk). Richard is a UK National Teaching Fellow, a co-operator at the Social Science Centre in Lincoln, UK, and a Trustee of the Open Library of Humanities. He writes about life in higher education at: http://richard-hall.org. 